\title{
Taxonomy and distribution of Eragrostis cumingii (Poaceae: Chloridoideae) in India
}

\author{
Vivek C.P.*, Lalji Singh \& Gautam Anuj Ekka \\ Botanical Survey of India, Andaman \& Nicobar Regional Centre, Haddo, Port Blair, \\ Andaman and Nicobar Islands - 744 102, India. \\ *E-mail: vvkcpoulose@gmail.com
}

\begin{abstract}
The recent record of Eragrostis cumingii Steud. from the Andaman and Nicobar Islands in addition to its earlier lone authentic report from Kerala in India is discussed with its present distributional status in the country. Its correct nomenclature, description, images and morphological difference with similar species, E. zeylanica Nees \& Mey. are also provided.
\end{abstract}

Keywords: Andaman and Nicobar Islands, Distribution, Eragrostis cumingii, India, Taxonomy.

\section{Introduction}

The grass genus Eragrostis Wolf comprises about 423 species, distributed in the tropical and subtropical regions of the world (Clayton \& Renvoize, 1986; Veldkamp, 2002; Ingram, 2010; Giraldo Canas et al., 2012). The genus is represented in India by 45 species (Vivek et al., 2015, 2016; Veldkamp et al., 2017). Recently, some interesting specimen of Eragrostis has been collected from the plains of South Andaman. On critical examination with the literature (Bor, 1960; Karthikeyan et al., 1989; Sreekumar \& Nair, 1991; Moulik, 1997; Pandey \& Diwakar, 2008; Kabeer \& Nair, 2009; Singh et al., 2014; Murugan et al., 2016), it has been identified as E. cumingii Steud., hitherto not recorded in the flora of Andaman and Nicobar Islands. This species is native to Taiwan, presently spread in temperate and tropical Asia, Australasia and North America. In India, the first authentic report of the species was made from

Received: 17.09.2019; Revised \& Accepted: 18.12.2019

Published Online: 31.12.2019
Thiruvananthapuram district in Kerala by Mohanan and Sreekumar (1982) based on the specimens, $M$. Mohanan 63327 (CAL, MH) and J. Christopher 267 (Kerala University Herbarium). In addition, authors also studied another gathering (V.S. Ramachandran 62649), collected from Kannur district in Kerala, probably overlooked by Mohanan and Sreekumar (1982), at CAL and MH. Khan et al. (2010) recorded E. cumingii from Maharashtra state based on the specimen, Tanveer Khan 1054, but without mentioning the herbaria wherein the specimen is housed, thus not traceable. Besides, it is evident from the description and illustration provided in the publication (2 stamens and distantly arranged spikelets on widely spreading panicle branches are not the characters of E. cumingii) that the above specimen was misidentified by the authors and belongs to another species. Therefore, the species record in Maharashtra state is not considered in the present paper. Furthermore, a few earlier collections of E. cumingii from the Andaman Islands and wrongly identified as E. zeylanica Nees \& Mey. were studied in CAL, MH and PBL. A comparative study between these specimens and authentic specimens of E. zeylanica housed at BSHC, CAL, $\mathrm{MH}$, and $\mathrm{BM}$ has facilitated the authors for confirming the correct identity of E. cumingii in India. The present collection forms the first report of the species from the Andaman Islands.

\section{Taxonomic treatment}

Eragrostis cumingii Steud., Syn. Pl. Glumac. 1: 266. 1854; Bor, Grass. Burma Ceylon India Pakistan 507. 1960; Mohanan \& Sreekumar, J. 
Econ. Taxon. Bot. 3: 447. 1982; Karthik. et al., Fl. Ind. Enum. Monocot. 216. 1989; Sreek. \& V.J. Nair, Fl. Kerala-Grass. 380. 1991. E. simplex Scribner, Bull. Div. Agrostol. U.S.D.A. 7(ed. 3): 250. 1900. E. distans Hack., Publ. Bur. Sci. Gov. Lab. 35: 81. 1906. Lectotype (designated by Lazarides, 1997): PHILIPPINES. Luzon, Cuming 1104 (K000290379 digital image!; isolecto BM, BRI, E, FI, G, L, MO, P, W).

Fig. 1

Annuals or perennials. Culms erect or decumbent, slender, 3-100 cm tall; nodes brownish; internodes
2-5 cm long, glabrous. Leaf sheaths $1.5-4 \mathrm{~cm}$ long, glabrous or sparsely tubercle based ciliate, mouth bearded; ligule a fringe of cilia; leaves mostly basal, filiform, 5-10 cm long, blades linear to lanceolate, apex acuminate, base more or less rounded, margins entire, upper surface sparsely ciliate. Panicle open, elliptic to oblong, 4-10 × 1-2 cm, with spikelets clumped along branches, branches alternate, short, 1-3 cm long, eglandular, angled, slightly scabrous along angles, base and axils densely ciliate; peduncle 3-13 cm long, striate, glabrous. Spikelets lanceolate
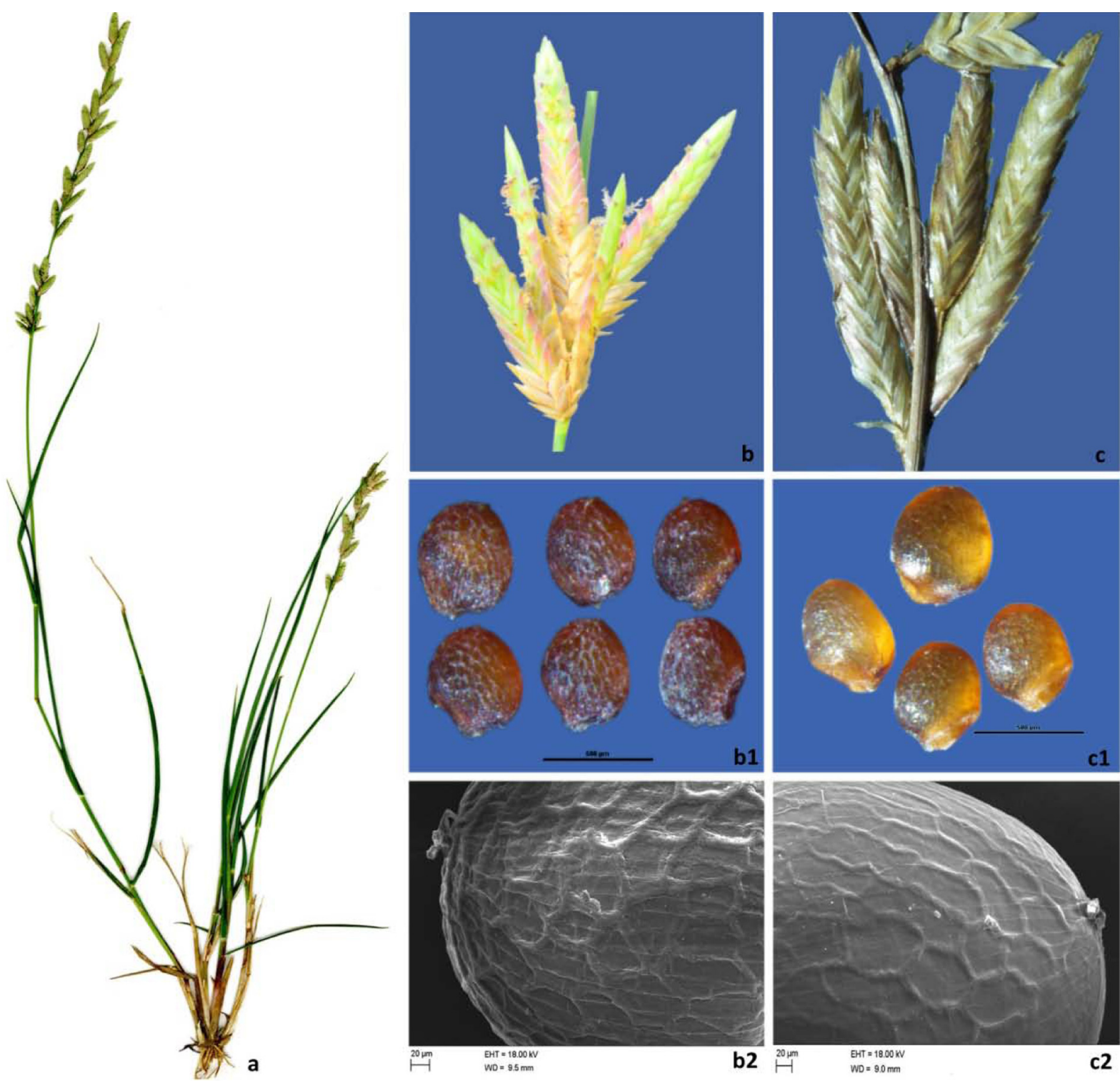

Fig. 1. a-b2. Eragrostis cumingii Steud. a. Habit; b. Spikelets; b1. Stereomicroscopic image of caryopses; b2. SEM image of caryopsis; c-c2. E. zeylanica Nees \& Mey. c. Spikelets; c1. Stereomicroscopic image of caryopses; c2. SEM image of caryopsis. 
to oblong, 5-10 × 1-2.3 mm, apex sharply acute, greenish to pinkish; pedicels short, stiff, 0.5-1.5 $\mathrm{mm}$ long, eglandular, angled, slightly scabrous along angles. Glumes deciduous, linear to lanceolate, apex acute to acuminate, margins entire, chartaceous to subcoriaceous, 1-nerved, keeled, scabrous along keel; lower glume 1-1.5 × 0.3-0.5 $\mathrm{mm}$; upper glume, $1.5-2 \times 0.5-0.7 \mathrm{~mm}$. Florets 10-30, breaking from below upwards, closely arranged on rachilla, pinkish; rachilla narrowly zigzag. Lemmas deciduous, ovate to lanceolate, 1.5$1.8 \times 0.6-1 \mathrm{~mm}$, apex acute, margins entire, subcoriaceous, 3-nerved, lateral nerves nearly straight, 1-keeled, slightly scabrous along keel. Paleas persistent, elliptic to oblanceolate, 1-1.3 × $0.2-0.4 \mathrm{~mm}$, apex acute to obtuse, margins entire, slightly curved, 2-nerved, 2-keeled, ciliolate along keels. Lodicules 2, c. $0.15 \mathrm{~mm}$ long, apex truncate, white. Stamens 3; anthers c. $0.1 \mathrm{~mm}$ long, purplish. Ovary ovoid, c. $0.1 \mathrm{~mm}$ long, pale green to cream coloured; styles c. $0.2 \mathrm{~mm}$ long, white; stigmas c. 0.3 $\mathrm{mm}$ long, white to cream coloured. Caryopses ovate to globose or orbicular, c. $0.5 \times 0.3 \mathrm{~mm}$, brownish.

Flowering \& fruiting: June-March.

Habitat: In plains and open places in forests.

Distribution: Temperate and tropical Asia, Australasia, North America.

Specimens examined: INDIA, Andaman and Nicobar Islands, South Andaman, Beadonabad, 30.11.1973, N.P. Balakrishnan 661 (CAL, PBL); Nayasahar, N $11^{\circ} 34.447^{\prime} \mathrm{E} 092^{\circ} 40.470$ ', 5 m, 04.03.2019, C.P. Vivek
33203 (PBL); Shippighat, N1135.543' E 092 40.497', 3 m, 25.01.2019, C.P. Vivek 33202 (PBL); Port Blair, 3 m, 12.01.1951, K. Thothathri 9042 (CAL, MH, PBL). Kerala, Kannur district, Chandanathode, $825 \mathrm{~m}$, 17.06.1979, V.S. Ramachandran 62649 (CAL, MH); Thiruvananthapuram district, Veli, 30 m, 30.07.1979, M. Mohanan 63327 (CAL, MH).

Notes: Eragrostis cumingii can be easily mistaken for a morphologically similar taxon, E. zeylanica Nees \& Mey. which is distributed in Bangladesh, Myanmar, Sri Lanka and India. Both the species closely resemble each other in a number of vegetative as well as floral characters. They have linear panicle with sharply acute spikelets clumped along branches, and florets are closely arranged on rachilla. Moreover, leaves exhibit panicoid type of microhairs (Vivek et al., 2016). However, E. cumingii has rather sprawling and taller culms as compared to E. zeylanica and more other distinct characters as depicted in figure 1 and table 1. Only a few authentic specimens of E. zeylanica could be studied in Indian herbaria, recorded from Kerala [V.S. Ramachandran 60035 (CAL \& MH); V.J. Nair 59997 (MH); C.P. Vivek 126160 (MH)], Sikkim [R.C. Srivastava 12118; 12114 (BSHC)] and West Bengal [Joh. W. Helfers.n., acc. no. 541918 (CAL)]. Other specimens wrongly determined in the herbaria as E. zeylanica are in fact belonging to $E$. cumingii. The Checklist of flora of Andaman and Nicobar Islands (Pandey \& Diwakar, 2008; Murugan et al., 2016) have included E. zeylanica, probably based on the collections of $K$. Thothathri

Table 1. Distinguishing characters of Eragrostis cumingii and E. zeylanica

\begin{tabular}{|l|l|l|}
\hline Characters & Eragrostis cumingii Steud. & Eragrostis zeylanica Nees \& Mey. \\
\hline Culms & Sprawling, wiry, 3-100 cm tall & Shortly spreading, stout, 5-25 cm tall \\
\hline Leaves & Mostly basal, filiform & Not basal, filiform \\
\hline Spikelets & $\begin{array}{l}5-10 \times 1-2.3 \mathrm{~mm}, \text { apex sharply acute, } \\
\text { greenish to pinkish }\end{array}$ & $\begin{array}{l}5-20 \times 0.1-3 \mathrm{~mm} \text {, apex sharply acute } \\
\text { to acuminate, greenish }\end{array}$ \\
\hline Florets & $10-20(-30)$ & $10-60$ \\
\hline Lemmas & $1.5-1.8 \mathrm{~mm}$ long, apex acute & $1.5-2.5 \mathrm{~mm}$ long, apex acute to acuminate \\
\hline Caryopses & $\begin{array}{l}\text { Ovoid to globose, prominently reticulate } \\
\text { on surface with isodiametric thick walled } \\
\text { broader cells, deep brown in colour }\end{array}$ & $\begin{array}{l}\text { Ovoid to subglobose, not prominently reticulate } \\
\text { on surface with isodiametric thick walled } \\
\text { broader cells, light brown in colour }\end{array}$ \\
\hline
\end{tabular}


9042 (CAL, MH \& PBL) and N.P. Balakrishnan 661 (CAL \& PBL). However, critical study on the specimens revealed that the gatherings belong to E.cumingii and included in the present paper under the latter as additional collections of the taxon examined in the Islands. So far, no authentic specimen of E. zeylanica could be traced in herbaria as occurring in the Andaman and Nicobar Islands.

\section{Acknowledgements}

The authors are thankful to the Director, Botanical Survey of India for providing facilities and encouragement. They are also thankful to Dr. G. Gnanasekaran, Assistant Professor, MCC, Chennai, for providing the SEM images of caryopses.

\section{Literature Cited}

BOR N.L. 1960. The Grasses of Burma, Ceylon, India and Pakistan (excluding Bambuseae). Pergamon Press, London.

CLAYTON W.D. \& S.A. RENVOIZE 1986. Genera Graminum, Grasses of the World. Kew Bulletin Additional Series 13: 1-389.

GIRALDO-CANAS D., PETERSON P.M. \& I. SANCHEZ VEGA 2012. The genus Eragrostis (Poaceae: Chloridoideae) in Northwestern South America (Colombia, Ecuador, and Peru): Morphological and taxonomic studies. Biblioteca Jose Jeronimo Triana 23: 1-180.

INGRAM A.L. 2010. Evolution of leaf blade anatomy in Eragrostis (Poaceae). Systematic Botany 35(4): 755-765.

KABEER K.A.A. \&V.J. NAIR 2009. Flora of Tamil NaduGrasses. Botanical Survey of India, Kolkata.

KARTHIKEYAN S., JAIN S.K., NAYAR M.P. \& M. SANJAPPA 1989. Florae Indicae Enumeratio Monocotyledonae. Botanical Survey of India, Kolkata.
KHAN T.A. CHAUDHARI G.S. \& P.A. PANDEY 2010. Eragrostis cumingii Steud. (Poaceae): A new grass record for Maharashtra. Indian Forester 136(5): 689-691.

MOHANAN M. \& P.V. SREEKUMAR 1982. On the occurrence of Eragrostis cumingii Steud. (Poaceae) in India. Journal of Economic and Taxonomic Botany 3: 447-448.

MOULIK S. 1997. The Grasses and Bamboos of India. Volume $1 \& 2$. Scientific Publishers, Jodhpur.

MURUGAN C., PRABHU S., SATHIYASEELAN R. \& R.P. PANDEY 2016. A checklist of plants of Andaman and Nicobar Islands. (Edited by P. Singh \& W. Arisdason). http://www.bsienvis.nic.in/Database/Checklist-ofAndaman-Nicobar-Islands_24427.aspx

PANDEY R.P. \& P.G. DIWAKAR 2008. An integrated checklist of plants in Andaman and Nicobar Islands, India. Journal of Economic and Taxonomic Botany 32: 403-500.

SINGH L.J., MURUGAN C. \& P. SINGH 2014. Plant genetic diversity of endemic species in the Andaman and Nicobar Islands In: National Conference on Islands Biodiversity, UP State Biodiversity Board, Lucknow. pp. 49-57.

SREEKUMAR P.V. \& V.J. NAIR 1991. Flora of KeralaGrasses. Botanical Survey of India, Kolkata.

VELDKAMP J.F. 2002. Revision of Eragrostis (Gramineae, Chloridoideae) in Malesia. Blumea 47: 157-204.

VELDKAMP J.F., THOIBA K. \& A.K. PRADEEP 2017. Eragrostis paniciformis (Poaceae): A new record for Asia from Kerala, India. Rheedea 27(1): 46-49.

VIVEK C.P., MURTHY G.V.S., GNANASEKARAN G., KABEER K.A.A. \& V.J. NAIR 2015. A study on the caryopses morphology of the grass genus Eragrostis in India. Nelumbo 57: 1-10.

VIVEK C.P., GNANASEKARAN G., MURTHY G.V.S. \& V.J. NAIR 2016. Microhairs of Indian Eragrostis Wolf (Poaceae) and their taxonomic significance. Nelumbo 58: 48-56. 